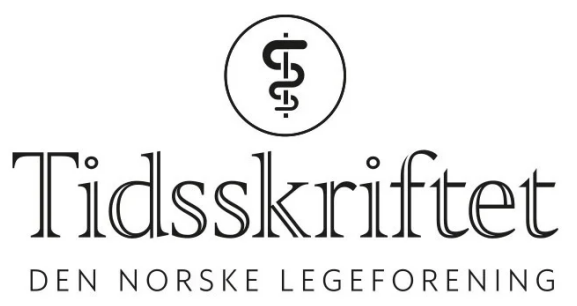

\title{
Norske tvillingsvangerskap gjennom 40 år
}

NYHETER

\section{ANNE FORUS}

Email:anneforus@hotmail.com

Tidsskriftet

Antall tvillingfødsler er doblet i perioden 1967-2004. Perinatal dødelighet blant tvillinger er fire ganger høyere enn hos enkeltfødte. Mors fødselsvekt påvirker risikoen. 




Anne Tandberg. Foto Jørgen Barth

Svangerskap med tvillinger og trillinger gir økt risiko for lav fødselsvekt, for tidlig fødsel og $ø \mathrm{kt}$ perinatal dødelighet. Anne Tandberg har bruk data fra Medisinsk fødselsregister for å studere forekomst og utfall av tvilling- og trillingsvangerskap i årene 1967-2006. Hun viser at antall tvillingfødsler i Norge har økt med $80 \%$ i denne perioden.

- Vi vet at assistert befruktning gir økt forekomst av tvillinger og trillinger. Men økningen av tvillinger er likevel 50 \% når vi ikke regner med disse svangerskapene. Høyere alder på fødende kvinner og $ø$ kt bruk av eggløsningsstimulerende medikamenter er noe av forklaringen. Trillingforekomsten ble tredoblet fra 1967 til midten av 199o-årene, også på grunn av assistert befruktning, sier Tandberg.

Den perinatale dødeligheten er redusert de siste tiårene, men i perioden 1988-2006 hadde tvillinger fortsatt fire ganger høyere dødelighet enn enkeltfødte. Trillinger hadde ti ganger høyere dødelighet. Dette kan delvis forklares ved at $10 \%$ av trillingene var født før uke 28 . Ved tvillingsvangerskap hadde gravide som selv var født før 32 . svangerskapsuke, firedoblet risiko for å miste en eller begge tvillingene, sammenliknet med kvinner som var født til termin. Risiko for å miste tvillinger var mer enn doblet dersom kvinnen veide under 2500 gram da hun ble født. 
- Et tvilling- eller trillingsvangerskap innebærer betydelig risiko både for mor og barn. Ved assistert befruktning bør det som hovedregel bare settes inn ett befruktet egg. Gravide som selv er født for tidlig eller hadde lav fødselsvekt, bør følges spesielt tett dersom de blir gravide med tvillinger, sier Tandberg.

\section{Ordforklaringer}

Perinatal dødelighet: Død som inntreffer fra 22. svangerskapsuke til en uke etter fødsel.

Publisert: 9. august 2011. Tidsskr Nor Legeforen. DOI:10.4045/tidsskr.11.0701

(C) Tidsskrift for Den norske legeforening 2023. Lastet ned fra tidsskriftet.no 26. april 2023. 